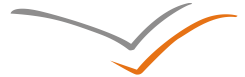 \\ VERSITA \\ UNIVERSITETI I EVROPËS JUGLINDORE

\section{Responses to EU rural development initiatives in the transitioning Republic of Macedonia's Tikveš wine region}

\author{
Justin M. Otten, PhD Candidate \\ University of Kent (Canterbury, UK), School of Conservation and Anthropology \\ Research Associate, Indiana University (Bloomington, USA), Department of \\ Anthropology \\ Email: jotten@indiana.edu / jo83@kent.ac.uk \\ DOI: 10.2478/v10306-012-0018-1
}

*This research was supported through an American Councils administered Title VIII Research Grant awarded to Justin Otten.

\begin{abstract}
This paper investigates the European Union's IPARD funding scheme at work in the Tikveš wine region of the Republic of Macedonia. Based on anthropology fieldwork carried out in Tikveš in 2011, it argues that for most farmers, the scheme's opportunities are unattainable. Primarily, participants must put down a substantial amount of money to take part in the program. Meanwhile, this occurs under the umbrella of post-industrialization and privatization, whereby the region's majority grape growers are undergoing a "catastrophic" transition and have had several years of unpaid harvests, if their grapes are even bought at all. The industry is in reality transforming itself due to market pressure, but for growers it appears that to survive increasingly requires turning to other means such as barter and subsistence living. Therefore, the growing disparity between the winery owners and the grape growers combined with the uncertainty of the latter's future means that most growers cannot imagine participating in a development scheme such as the IPARD. This paper will thus elaborate on the policies behind it and the specter of EU integration for the Tikveš region.
\end{abstract}

Keywords: privatization, IPARD, European integration, post-socialist transition. 


\begin{abstract}
Abstrakt
Ky punim hulumton në vepër skemën e financimit IPARD të Bashkimit Evropian për rajonin e verës të Tikveshit në Republikën e Maqedonisë. Bazuar në punën antropologjike të bërë në terrenin e Tikveshit në vitin 2011, punimi argumenton se për numrin më të madh të fermerëve, mundësitë e skemës janë të paarritshme. Kryesisht, për të marrë pjesë në program, pjesëmarrësit duhet të japin një sasi të konsiderueshme parash. Ndërkohë, kjo ndodh nën ombrellën e post-industrializimit dhe privatizimit, ku shumica e kultivuesve të rrushit në këtë rajon i është nënshtruar një tranzicioni "katastrofik" dhe ka pasur disa vite të të korrurave të papaguara, nëse rrushi i tyre është blerë fare. Industria është në fakt duke e transformuar veten për shkak të presionit të tregut, por për kultivuesit duket se, për të mbijetuar, kërkon kthim gjithnjë e më të madh në mjete të tjera siç janë këmbimi dhe prodhimi për nevoja individuale. Prandaj, pabarazia në rritje ndërmjet pronarëve të verëtarive dhe kultivuesve të rrushit kombinuar me pasigurinë e të ardhmes së këtyre të fundit do të thotë se shumica e kultivuesve nuk mund ta imagjinojnë pjesëmarrjen në një skemë të zhvillimit siç është IPARD-i. Në këtë mënyrë ky dokument do të elaborojë politikat dhe spektrin e integrimit të BE-së për rajonin e Tikveshit.
\end{abstract}

\title{
Апстракт
}

Во рамките на овој есеј е претставено истражувањето на практичната ефикасност на ИПАРД, финансиската програма на Европската унија во Тиквешкиот вински регион на Република Македонија. Врз основа на антрополошкото практично истражување спроведено во Тиквешкиот регион во 2011 година се потврди дека за повеќето земјоделци можностите за користење на средствата од програмата ИПАРД се недостижни. Првенствено, за да учествуваат во оваа програма учесниците мора да кофинансираат со значителен износ на финансиски средства. Во меѓувреме, ова се случува под закрила на постиндустријализацијата и приватизација при што поголемиот број на лозари од регионов се подложени на „катастрофална" транзиција надополнета со неколку години неплатени реколти, ако грозјето, всушност, првично е откупено. Во реалноста, индустријата се трансформира под влијание на пазарниот притисок, но за лозарите се чини дека за да преживеат ќе мора да се пренасочуваат кон други опции, како што се размена (трампа) на стока и лично прозведување за преживување. Затоа, растечката разлика помеѓу сопствениците на винариите и лозарите во комбинација со неизвесноста на иднината на вторите значи дека повеќето лозари не можат да замислат учество во развојна програма како што е ИПАРД. Според претходно кажаното, овој есеј ќе се осврне на соодветните постечки регулативи и на сеништето на интеграцијата на Тиквешкиот регион во ЕУ. 


\section{Introduction}

Crno e, Tikveško e

"It's black, it's [from] Tikveš" is a well-known lyric about the dark red wine produced in the south-central Tikveš region of the Republic of Macedonia. Grape products (wine and brandy primarily) from the region are among Macedonia's main agricultural exports, and in a country where nearly a fifth of the workforce is involved in agriculture, their role in the country's economy is thus significant. In Tikveš, this percentage is even greater, as half of the local population grow grapes or other agricultural products.

Grapes have supposedly been grown in Tikveš for millenia, though without doubt industriously since the middle of the $20^{\text {th }}$ century when Tikveš was developed into Yugoslavia's (and Southeast Europe's) largest wine region. Although Yugoslav growers could maintain a small amount of private land (up to ten hectares) and had the choice of where to sell their produce, the state-run (and only) large wineries in Tikveš paid well with little regard to quality and were thus the primary buyers of the individual growers' grapes.

These relationships between growers and buyers continued throughout the 1990s despite the country's independence in 1991. With privatization a slow process, the largest winery in the country, called Tikveš Winery, was not fully privatized until 2004, when shareholder and millionaire businessman Sveto Janevski bought a majority stake in and took full control of it. What followed was the liquidation of employees, decreased production and thus grape purchasing, and a shifting of the winery's ownership and administration to the country's capital, Skopje.

This is the most catastrophic, but is just one example of privatization in the wine industry in the Tikveš region. Overall, privatization has more recently culminated and exacted itself through higher standards expected by the wineries for quality wine production, decreased grape purchasing, and severely low prices paid, if growers are paid at all. Indeed, many have seen several years of unpaid or under-paid harvests. At the same time-since 2005 specifically - the country has been a candidate for EU membership. In preparation for eventual entry into the Union, the Macedonian government has been complying with the EU's Instrument for Pre-accession Assistance, or IPA. Through the IPA, Macedonia has received half a billion euros since 2007 for five components, from institution building to rural development. My research here, based on anthropological doctoral dissertation fieldwork conducted in 2010-11, focuses on the rural development (RD) component, known as the Instrument for Pre-accession Assistance for Rural Development, or IPARD, and its role in the transition in Tikveš.

\section{The IPARD and rural development in Macedonia}

The IPARD program was adopted by the European Commission (EC) in February 2008 through the National Agriculture and Rural Development Plan. Its overall objective is to "support implementation of policies to promote competitive and sustainable agriculture; develop strong and sustainable communities, and diverse and sustainable rural environments" (Delegation of the European Union, Fact Sheet 2010/03). Although the bulk of the funding comes from EU taxpayers, the management of the IPARD is the responsibility of the national authorities - the Macedonian government and its respective ministries. Together they are to 
ensure the existence of sound financial management and implementation of the funds, including the required structures, rules, and procedures.

Overall, the IPARD program is designed to "improve the technological and market infrastructure of commercial agricultural holdings and the food processing industry, aiming to increase the added value of agri-food products and achieve compliance with EU quality, health, food safety, and environmental standards, while at the same time assuring the quality of life of the rural population, increasing rural incomes and creating new employment opportunities." Furthermore, "the main beneficiaries of the measures...will be: agricultural holdings, agriculture cooperatives, food industry, rural economic operators, rural entrepreneurs, and the rural population as a whole" (ibid).

The IPARD program is thus significant for a predominantly agricultural country such as Macedonia, as its clearly stated aims are to transform not only the agricultural industry in Macedonia, but also the communities in which they exist. Yet such reorientation of production is difficult, as rural producers are rarely capable of generating the required capital needed for change themselves, particularly such as the IPARD program calls for. Furthermore, as David Kideckel (1995) observed early on in Romania's post-communist transition, agriculture is a unique branch of industry because land is a fixed and limited resource, and influenced by local customs and conditions which growers cannot quickly adjust to external demands such as those imposed by market-development priorities.

In Tikveš, social relations and different customs surrounding production mean that growers see little incentive at present to shift to another crop, particularly when grapes are not only what they have produced for so long, but like other crops, require a significant initial financial investment and several years of growth before literally "bearing fruit." Who would rip up their land in order to plant other produce which might take just as long to create revenue at best, and which in all probability will not have a solid market in the near future? No one can blame growers in Tikveš for lacking the inclination to take such chances, yet this leaves them anything but confident in the future of their livelihoods. They continually ask whether there will be demand for their grapes or other produce in the future, and wonder whether the country will ever even join the EU. Only a few business-minded growers and traders consider EU membership in terms of market opportunities, but with the European financial crisis, "Euro-skepticism" runs high. The Europe of a decade ago thus seems to be an increasingly distant utopian ideal.

In addition to the IPARD program, the rural development plan for Macedonia is outlined in great detail in a 486 page document produced by the European Bank for Reconstruction and Development (EBRD). One of many observations within the text is the following: "Wine grape producers suffer from several management problems. Grape producers do not have the ability to obtain credit, or to influence raw materials supply, exert price control of the grape, and ensure timely payments for their deliveries" (EBRD FYR Macedonia Strategy, 2010, pp.70-71). Therefore, what we see here are powerless growers facing a multi-pronged EU policy that is formed with knowledge of growers' limited resources, yet is nonetheless intent on downsizing wine-grape production through standardization, regulation, and big-business development. From an EU perspective, this aim is somewhat understandable, as the European wine-market is both saturated and competitive. Yet, one study states that "the only direction in which trade with Southeast Europe is expected to occur with EU countries is in viticulture and the wine trade" (Totev \& Shahollari, 2001). That is, direct competition with other EU grape growers and wine producers is expected to significantly challenge the country's wine industry from 2013 - when Macedonia must cease its tariffs on EU member-state wine imports - and Macedonia does not stand to gain much from its other agricultural produce due to domination by suppliers in other EU countries and Africa. Further, because the EU's 
agricultural policy has traditionally rewarded farmers who produce more, larger farms (of which there are none owned by actual growers in Tikveš) benefit far greater from subsidies than smaller ones, such as the family-labor holdings of Macedonia and the former Yugoslavia in general (OECD, 2010). Therefore, Tikveš is in transition, yet the blueprint for the region's future may not be the most compatible with the EU nor viable for the country's wine industry.

\section{The transition in Tikvě̌}

It seems apparent that the complications associated with the shift to European agricultural standards in Tikveš are deep-seated, and make it essential to look at the balance of power, the social relations of production, and the local experience with the transition there. For in reality, policy coming from Brussels and implemented through Skopje seems to morph along the way. This is not only because the government has its own interests and concerns with how its agricultural industry is run, but because the on-the-ground reality of implementation in a country like Macedonia depends not just on bureaucratic measures and funding, but social relations and connections. In short, there is an "economy of favors" at work in Macedonia. By that I assert that most individuals must dance around social relations, and even at the administrative level they must express deference, utilize connections, and return favors for assistance with whatever endeavors they partake in. For the Tikveš region of Macedonia, although Balkan and part of the former Yugoslavia, is also very Mediterranean in character, and such as elsewhere in Southern Europe, there is a social collectiveness that dictates norms and customs.

In my fieldwork, I therefore not only looked into how the IPARD's focus on rural development is implemented and utilized, but I considered the cultural influence from a local perspective. For while national ministers and EU bureaucrats may idealize that rural agricultural development measures such as that of the IPARD can be taken advantage of by any citizen with the will to do so, this does not reflect the various "transcripts" (Scott, 1985) - the socially hierarchical expectations - at work and is thus simply not the case.

By attending several of the IPARD presentations and regularly visiting the local Rural Development Agency office in Tikveš, I conversed with growers and bureaucrats about the IPARD program. What was most evident from these conversations was that the procedural steps for the IPARD application are not only a series of significant obstacles, but are virtually impossible for most citizens and grape growers there. This is because the application includes gaining access to credit, providing half of the funding for a project which must cost at least 5,000 euros; providing documentation that verifies ownership of the land to be worked or built on; presenting various permits and official registration forms verifying one is a registered agriculturalist (zemjodelec); and last but not least, having the connections to see through the combination of these into a viable and successful application.

Another problem with the IPARD has been poor advertising and attempts to draw potential applicants to the presentation sessions held. Throughout the bulk of my fieldwork in 2011, during which there were four rounds of applications and funding for the IPARD, only in a few locations did I see posters advertising the program beyond the Rural Development Agency office. Yet for those that I knew and met who were aware of the program and attended such presentations, they indeed perceived the application process as extremely complicated at best, and often impossible given a lack of official documentation, a solid business plan, and accessible credit needed to match the IPARD grant. 
As an example, on a hot day in July 2011 I drove to the small Tikveš town of Demir Kapija specifically for an IPARD presentation. The presenters, however, rapidly went through a lengthy and difficult to read Power Point presentation. Lasting just a half-hour altogether, two representatives from the Agency office showed slides on a screen behind them on the stage of the town's cultural center. But because of small letters and an overabundance of text on the slides, they were unreadable. The presenters then proceeded through the details of the application and asked for any questions, but rather hastily answered the two they received. One was from an apparent farmer asking about a parcel of land in a certain vicinity of the municipality and whether it was suitable for IPARD rural tourism funding (it was not), and the other was about developing beehives for honey production. This was possible, but the answer to it reflects the natural difficulty most interested individuals face: although the IPARD's funding could support honey production, the total application expenses must be at least 5,000 euros for there to be any agreement and contribution from the IPARD. Many growers, however, cannot fathom matching half of that (2,500 euros or more), as such a sum is the majority of an average year's earnings in rural Macedonia. Consequently, they must dismiss the idea of participating, as this grower seemingly did in muttering in disbelief at the amount of money he would have to contribute.

In consideration of this and in terms of the IPARD, we therefore see a dilemma. On the one hand, the EC's representative, Gerrard Quille, stated "This is [just] the beginning for Macedonian farmers. Some of them are not used to the conditions [required] and they do not know exactly how to submit applications. Yet the number of rejected applications decreases every year" (Angelovska, 2011). On the other hand, there is an evident tendency for the IPARD program to support those who already have the finances to invest, as all of the successful applications I was aware of came from individuals who were most often businessmen, some actual winery owners, and all who were considered well to do.

\section{Conclusion}

In conclusion, I suggest that the EU, through the IPARD in this case, is using economic and political muscle to change a less-developed system than its own in Macedonia into the form it sees fit, and without concern for the toll this takes on the large majority of the population. Further, it is due to a cultural misunderstanding that the EU continues on this path, for the faith it invests in the Macedonian authorities to ensure equal opportunity in the IPARD funding process is in reality met on the ground by a cultural milieu whereby patronclient and kinship relationships, and the power that comes through them, supersede institutional authority. The latter, which the EU is in part attempting to establish through the IPARD's distribution of EU taxpayer money, is indeed only one layer of Macedonia's diverse social strata and the "transcripts" which play out through them. Therefore, in attempting to modify Macedonia's agricultural sector and conform it to EU standards, the IPARD may be, to borrow from the Macedonian saying, trying to "bury the vine and drink the wine" (bucni prčka, pij vino). Said to those expecting too much, too fast, the EU may be guilty of not only aiming too high, but missing the mark in terms of understanding what needs reforming in Macedonia. 


\section{References}

1. Angelovska, V. (2010). Mladite ne se fakjaat za motika. Dnevnik, November 23, 2010.

2. Angelovska, V. (2011). Zemjodelci teshko do IPARD-krediti. Dnevnik, May 14, 2011.

3. Angelovska, V. (2011). Agrarot ne gi koristi IPARD-sredstvata. Dnevnik, June 24, 2011.

4. Delegation of the European Union (2010), Fact Sheet 2010/0.

5. European Bank for Reconstruction and Development (2010) FYR Macedonia Strategy.

6. Available from: http://www.ebrd.com/about/strategy/country/mace/index.htm

7. Hann, C. (2006). "Not the horse we wanted!" Postsocialism, neoliberalism and Eurasia. Lit Verlag: Munster.

8. Kideckel, D., ed. (1995) East European communities: the struggle for balance in turbulent times. Westview Publishers.

9. Scott, J. (1985) Weapons of the weak: everyday forms of peasant resistance. Yale University Press.

10. Totev, S. and Shahollari, L. (2001). Agriculture development and trade in Bulgaria, FYR

11. Macedonia, and Albania in the context of the Common Agriculture Policy. Southeast Europe Review for Labour and Social Affairs. Issue 03/2001, pp.51-69. Available at www.ceeol.com 